\title{
DISCURSO DE ORDEN PRONUNCIADO POR EL CATEDRATICO DE LA HISTORIA DE AMERICA Dr. PEDRO DULANTO
}

Señor Representante del Presidente de la República.

Señor Ministro de Educación Pública y señores Ministros de Estado.

Señor Rector.

Señor Embajador de la República Argentina y señores miembros del Cuerpo Diplomático.

Señor Presidente del Instituto de Cultura PeruanoArgentino.

Señoras y señores:

La Universidad Mayor de San Marcos se asocia al homenaje que tributa la República Argentina a la memoria de uno de sus más extraordinarios hijos, Domingo Faustino Sarmiento, en el cincuentenario de su muerte, acaecida el 11 de setiembre de 1888 en Asunción del Paraguay, para continuar desde la inmortalidad, señalando rumbos a su patria y a América, por su pensamiento genial, por la fecundidad de su obra intelectual y política $\mathrm{y}$, principalmente, por su apostolado educativo, sostenido con admirable constancia, por medio de sut voluntad vigorosa desde su juventud hasta el fin de su prolongada, combatida y gloriosa vida.

El ambiente familiar y ef de la provincia "argentina de San. Juan donde naciera Sarmiento el 15 de febrero de 1811, influyeron decisivamente en su porvenir. El mismo Sarmiento en "Recuerdos de Provincia", la más castiza y humana de sus obras, en la que exigentes críticos encuentran reminiscencias del propio Cervantes, en la relación de las anécdotas, cuenta de la pobreza de los suyos, abrumado el padre por rudo trabajo material, pero siempre pendiente de la educación de su hijo; ocupada la madre en confeccionar para la venta primorpsas obras de mano para así adquirir el derecho de poder decir, cumplidos los 65 años de eda:d, cierto día de fiesta en Aconcagua: "es la primera vez en mi vida que me paso mano sobre mano".

Fué Sarmiento desde niño gran aficionado a la lectura, haciendo sus estudios preiliminares bajo la dirección de dos parientes suyos, clérigos ambos, pero de liberal espíritu, para seguir por cuenta propia, sin maestros ni colegios, adquiriendo variados conocimientos en ciencias exactas, historia, filosofía y literatura. Hacía Sarmiento sus estudios sin orden y sin método pero justamente, 
de esa misma dispersión surgían merced a su poderosa inteligencia, el pensamiento independiente, la facultad de observación, la voluntad pronta, la radical seguridad de si mismo que caracterizó en todo tiempo la obra y la vida del grande hombre argentino.

Pero no fué solo afán por aprender el suyo, sino, también, grande afán por enseñar. A los 15 años, niño por la edad, pero hombre por la afirmación del carácter es ya maestro de escuela, restando tiempo a las atenciones que le requería su empleo en un pequeño comercio de telas. Unicamente los libros consolaban a Sarmiento y le hacían pensar que no estaba solo en el mundo, entre fardos de tocuyo y otros parecidos artículos.

Por las mañanas, luego de barrer la tienda, este niño sufrido pero no vencido, se sentaba a la puerta con un libro en las manos, escandalizando a una conocida señora de San Juan, que al verlo así, inmóvil, mientras ella iba y venía de la Iglesia, decía después en su casa: "El mocito no debe ser bueno, si fueran buenos los libros no los leería con tanto ahinco".

Los libros que con mâs avidez leía Sarmiento eran de Historia Antigua, la de Grecia y la de Roma, preferentemente.

Otra lectura que le causaba hondas meditaciones era la de la Biblia que practicaba en las noches para discutir al siguiente día con su tío el clérigo Albarracín, haciéndole diversas observaciones. Los enciclopedistas fueron predilectos suyos. Libros de matemáticas y de agrimensura no le faltaban, aficionado a obras de ingeniería reparó un puente, aficionado al dibujo levantó el plano de la Catedral y de varias calles desu provincia.

Un gran hombre americano, Benjamín Franklin ejemplo de perseverancia y de fe, fué el modelo adoptado por Sarmiento. "Nada más edificante escribe, que ese joven que sin otro apoyo que su razón, pobre y destituído, trabaja con sus manos para tivir, estudia bajo su propia dirección, se da cuenta de sus acciones para ser más perfecto, ilustra su nombre, sirve a su patria ayudándola a desligarse de sus opresores, y un día presenta a la humanidad entera un instrumento sencillo para someter los rayos del cielo, y puede vanagloriarse de redimir millones de vidas con el invento con que dotó a los hombres, debiendo estar en los altares de la Humanidad y ser mejor que Santa Bárbara, abogada contra rayos y llamarse el Santo del pueblo".

Por paradoja de su espíritu, declaraba Sarmiento su aversión por los versos y alguna vez, en sus días de triunfo, sostuvo reñida polémica con Mitre sobre la inutilidad de los poetas y de la poesía, dando a su caprichosa opinión una justificación política, afirmando que los pueblos americanos cultivaban el verso como sumisión y por resabio de la cultura de España, con la que él, injustamente, nunca simpatizara. 
Pero si no poesía rimada, poesía del corazón y poesía de la acción habría de sentir el adolescente Sarmiento, cuando en su pobre provincia vagaba por los bosques y trepaba por los cerros aspirando el aire libre del eampo, enseñando en las escuelas y conversando en las cabañas de sus paisanos y el color y la forma y el alma del paisaje penetraban en su propia alma, cuando éste recogía en el silencio de las noches los rumores vagos o lejanos diluídos las estrellas en el azul puro del cielo, uniéndose en su espíritu multiforme la suprema emoción de lo infinito y el inmenso acorde de la libertad y de la gloria.

Recordemos que Sarmiento nació cuando iba a cumplirse un año del 25 de mayo de 1810, fecha en la cual fué depuesta en Buenos Aires la autoridad virreinal de Baltasar Cisneros, inaugurándose el primer gobierno nacional argentino denominado "Junta Provincial Gubernativa". De esa fecha a la época en que comienza a manifestarse la inteligencia natural y la voluntad recia de Sarmiento ha pasado la revolución argentina por las más du. ras pruebas, acreditanda la existencia de un firme propósito, hasta alcanzar, más tarde la conciencia de una causa de independencia y de libre gobierno. "Los nacidos en indias cuyos espíritus no tienen hermandad con el abatimiento, no son inferiores a los españoles europeos y a nadie ceden en valor" había dicho desde 1807, Cornelio Savedra jefe del batallón de tos Patricios y Presıdente de aquel primer gobierno enáciomaleenoBuenos Aires, que con su audaz golpe político, radicó allí el pensamiento de la revolución argentina, convirtiendo a la ciudad en depositaria de los recursos que habrían de distribuirse por todos los ámbitos del Río de la Plata.

Sarmiento en su provincia y por su juventud no podía valer todavía como orientador en este período convulso y dramático de la nacionalidad argentina, pero en comunicación consigo mismo adquirirá una idea viva del servicio público, arraigada en su alma y compendiada en la acción, porque pensamiento y vida fueron siempre en él la misma cosa.

Su razón y sus estudios le sugieren ideales, pero estos se resuelven, sin intervalo de tiempo en acciones. El impulso y la transición y el cumplimiento inmediato de sus propósitos eran el fuego ide su vida y en gran parte, la causa de sus defectos, que le depararan posteriormente tremendas enemistades.

Convencido de sí mismo, dice: "Yo he creído desde niño en mis talentos, como un propietario en su dinero o un militar en sus actos de guerra.", pero también son suyas las siguientes pala- 


\section{$-362-$}

bras reveladoras de una tierna realidad, que está en el fondo de todas sus apariencias. "He evocado mis reminiscencias, he resucitado, por decirlo así, la memoria de mis deudos que merecieron bien de la patria, y honraron con sus trabajos las letras americanas, he querido apegarme a mi provincia, al humilde hogar en que he nacido, débiles tablas, sin dưda, como aquellas flotantes en que en su desesperación se asen los náufragos, pero que me dejan advertir a mí mismo que los sentimientos morales nobles y delicados existen en mí, por lo que gozo en encontrarlos en torno mío, en los que me precedieron, en mi madre, en mis maestros, y en mis amigos".

Por la violencia de su carácter y por su amor a la libertad, emprende Sarmiento el camino del destierro rumbo a Chile, antes de cumplir 20 años de edad.

En la Historia de la Revolución Americana, figura la Alianza Argentino-Chilena como la primera en el Nuevo Mundo, llevada a cabo por naciones que a pesar de su distinta índole, unen sus fuerzas en un común propósito emancipador, acreditando de esta manera la existencia de un fuerte vínculo moral y social.

Posteriormente fué Chile el generoso refugio de los desterrados argentinos, y en uno de sus pueblos se estableció Sarmiento dirigiendo una escuela oficial, para volver pocos años después a su provincia de San Juan y volver también a sufrir, esta vez por prolongado tiempo, nuevo destierro, regresando siempre a Chile donde conoció a Manuel Montt, ministro entonces, que se convirtiera en generoso protector suyo, sin que Sarminto le hubiera olvidado jamás, admirando ycelogiańdo el tatento y la dignidad cívica de este ilustre estadista chileno, que no obstante su moderado espíritu, le dice, al serle presentado Sarmiento, dándole ánimo "las ideas, señor, no tienen patria" y que cormo él, ereyó y tuvo fé en la educación. popular como programa de gobierno. El espíritu combativo de Sarmiento le llevó en Chile, directamente a las filas del periodismo, publicando en "El Mercurio" de Santiago, sensacionales artículos contra el gobierno de Juan Manuel de Rosas, imperante entonces en la República Argentina.

Finalizada la etapa heroica de la independencia, tuvieron que emprender las antiguas colonias de España sin preparación alguna, la difícil obra del gobierno propio en una sociedad que arrastraba consigo antiguos vicios, inconforme, perturbada, desviada en sus fuerzas, propicia, por consiguiente, a la anarquía que sucedió al proceso de la emancipación. Y es por eso que cuando Bernardino Rivadavia, "el primer hombre eivil argentino" al decir de Mitre, el que sólo vió la superficie pero no el fondo, al decir de Alberdi, cerró los ojos a la crisis que se presentaba y dijo: "Soy la razón y no quiero ser la fuerza", abrió, sin quererlo, las puer- 
tas de gobierno al estanciero Juan Manuel de Rosas, exageradamente execrado por unos, exageradamente rehabilitado por otros, sin lugar seguro todavía en la historia de la República Argentina.

Sarmiento combate implacablemente al "Restaurador" a su "Mazorca" y a su "Reglamento". El espectáculo sangriento y su aIdiente amor a la justicia no le permiten advertir como, por eausas sociales profundas, un realismo oportunista y feroz, puesto al servicio de una administración sólidamente organizada y a un altivo nacionalismo, será el caro precio de la unidad política de la República Argentina. En Chile el año 1841, en folletín que va apareciendo en "El Progreso" de Santiago, improvisó Sarmiento día a día, para no desmentir su falta de orden, "Facundo" su inmortal obra de combate y de subido valor literario, traducida a cinco idiomas, anatema contra el materialismo y canto épico al valor de la cultura intelectual, sin ser "Facundo" un libro de historia si se le juzga con arreglo a la verdad histórica y a lo que el mismo Sarmiento confiesa subre su afamada prcłucción, recomendándola, "como un fruto le la improvisación del momento", como un "mito", a la manera de su "héroe".

"Facundo" es la vida de Facundo Quiroga, el caudillo de los Ilanos ,gaucho, tapiador en sus orígenes, imperioso, rudo, sombrío y valiente, rebelde a la autoridad dado de alta ocasionalmente en las milicias de los llanos y en carrera vertiginosa, convertido de simple Facundo en el Sr. Brigadier General don Juan Facundo Quiroga.

Infunde pavor este primitivo produeto de la pampa.

Un día, despuéśde habercinrohibidonquesnadie beneficiara reses, para que así el negocio fuera solo suyo encuentra a un paisano que ha violado la orden y que solo al ver a Facundo, aterrorizado, cae muerto.

Pero no le falta inteligencia y le sobra astucia.

Otra vez descubre un robo en el cuartel, hace formar la tropa y le da a cada soldado una vara de madera para poder reconocer al día siguiente al ladrón, en el que tenga la vara que ha crecido. El eulpable, temiendo que esto ocurra, ha recortado la suya, y Facundo, la deseubre, con parecida sabiduría a la que empleó Salomón para descubrir a la verdadera madre, ordenando partir al niño en dos.

Plantea Sarmiento en "Facundo" una irreductible oposición entre los earacteres de la tierra genuina y las costumbres de Europa, entre el campo y la ciudad, que constituyeron, sin duda, en los albores de la nacionalidad argentina pero no ahora, en que entran como elementos integrantes de la misma, dos factores disímiles, por obra de la naturaleza y de los hombres.

Sarmiento describe con maestría de artista, aquellos inmen- 
tidos, de su fe en sí mismo, que era la respiración de su alma primitiva, pero sin embargo, abierta a la contemplación poética de la vida, fuera de los arreglos y convenciones de los hombres, en las profundidades de la tierra, en las soledades del desierto o en la ruda majestad de la selva.

Planteada la lucha entre la ciudad y el campo, se origina la guerra civil, la terrible guerra civil argentina entre unitarios y federales, sostenedores los unos de la hegemonía política de Buenos Aires, del gobierno central en la gran ciudad de Mayo; propulsores los otros de la unidad política del país, dentro de la necesaria autonomía de sus provincias.

Sarmiento ve únicamente, ya lo dijimos, el espectáculo espeluznante y cruel que deja el paso de esos caudillos bárbaros, Facundo Quiroga uno de ellos, que llevan, no obstante en la punta de sus lanzas homicidas el porvenir político de la nacionalidad argentina, derribando las tendencias aristocráticas y las oligarquías que asomaron a raíz de la revolución de Mayo y abriendo paso para lo futuro, precisamente a la clase sin privilegios a que pertenecía Sarmiento, ufano siempre de su nobleza democrática, sustentada en trabajo y en su genio.

Pero si Sarmiento fué unitario por las razones que quedan expuestas. fué federal por los principios que sustentó y por los actos que practicó, porque como escribe Ricardo Rojas "no puede ser considerado sino como fecteral quien prohijó la Constitución de 1853; quien defendió como gobernador de San Juan, más tarde, los derechos autónomos de tos gobiernos provinciales; quien ratificó después como ministrogen losc EstadosoUnidososu vocación federal; y quien, en la versión inglesa de "Facundo" (1867-1873), sugirió a mister Mann el prólogo en que explica esta génesis de sus ideas, Así resulta en nuestra historia, agrega Rojas, este aparente absurdo; que los caudillos "federales" dominados por Rosas, rehicieron la "unidad argentina", rota por los unitarios quiméricos de 1826 ; y que los emigrados "unitarios" promulgaron la "federación" al regresar al país después de Caseros".

Mas no se limitó Sarmiento en estos años de su vida en Chile a abrir solamente campaña escrita por las ideas y por la cultura, puesto que "Facundo", llamado en sus primeras ediciones "Civilización y Barbarie" es en suma rotunda condenación a la ignorancia y un himno ardiente al saber, sino que, además, fué Sarmiento, consecuente con su vocación de maestro, fundador y director de la primera escuela normal establecida en Chile, en donde acaba 
de conmemorarse el Centenario de tan importante acontecimiento intelectual.

El ansia de cultura de Sarminto le capacita excepcionalmente para perfeccionarse en medios superiores, partiendo a Europa y a los Eistados Unidos de Norte América, en misión que le encomendara su ilustrado amigo el ya nombrado estadista chileno Manuel Montt, a fin de estudiar en esos grandes centros el estado de la instrucción pública. Sarmiento correspondió con exceso al honroso encarga conferido, y como producto de sus estudios, de sus investigaciones y de sus meditaciones sobre unos y otras, eseribió para el Gobierno de Chile su famosa obra "Edueación Popular", testimonis irrecusable 'de su amor ilimitado a la enseñanza y de su fe creciente en la educación pública. La obra que por si sola sería suficiente para ilustrar el nombre de Sarmiento, si no estuviese dignificado y glorificado por mil motivos más, representó en la historia de la pedagogía americana, en la fecha en que fué escrita, el año 1849 , el más audaz y a la vez concienzudo proyecto de educación popular, por sus anticipaciones, por sus ensayos, por sus verdades, vivas aún muchas de ellas, por sus propósitos liberales y por su sed, en fin, de sincera justicia social.

Apóstol de la democracia inspirado en el ideario político de Lincoln, conocedor por experiencia, de la vida de los desheredados, sustenta Sarmiento el derecho de todos los hombres a los bienes de la instrucción y el deber de-todos los gobiernos de procurarla y difundirla, supliendo las desventajas propias de los que nacen sin recursos suficientes. Acentúa el concepto cabal de que el poderío de los Estados radica en la aptitud industrial, moral e intelectual de sus habitantes y propugna en la educación popular, la superior finalidad de desarrollar y perfeccionar tales imponderables fuerzas.

A este propósito, escribe: "la dignidad del Estado, la gloria de una nación no puede cifrarse sino en la dignidad de condición de sus súbditos, y esta dignidad no puede obtenerse sino elevando el carácter moral, desenvolviendo la inteligencia y predisponiéndola a la acción ordenada y legitima de todos las facultades del hombre". Y luego preocupándose del orden, como que en su ánimo influyó sensiblemente el medio equilibrado de Chile, continúa: "Hay, además, objetos de previsión que tener a la vista al ocuparse de la educación pública y es que las masas están más dispuestas al respeto de la propiedad y de la vida a medida que su razón y sus sentimientos morales están más cultivados. Por egoísmo, pues, de los que gozan mayores ventajas en la asociación debe tratarse cuanto antes de embutir el instinto de destrucción que duerme ahora y que habrán de despertar la vida política y la influencia de las ideas". 


\section{$-367-$}

El inmortal libro abarca en sus páginas, claras y didácticas, todos los problemas de la época sobre la enseñanza primaria, informando acerca de los adelantos europeos al respecto, especialmente, en Suiza, Francia e Inglaterra y en los Estados Unidos de Norte América, dentro de una inteligente adaptación al medio sudamericano y en especial al de Chile, en euyo ambiente educativo brillaba su docta Facultad de Humanidades.

La implantación de las escuelas normales para la formación de los maestros ocupa capítulo central en la obra "Educación Popular" y en el programa de acción educativa de Sarmiento, a fin de evitar "que cada maestro invente el arte de enseñar y lo deje morir con él para renacer de nuevo en el que le sucede". Los reglamentos de enseñanza primaria, la inspección de las escuelas, la disciplina escolar, los elementos precisos para la salud y el desarrollo físico de los escolares, el empleo del tiempo, las lecciones de cosas, por costumbres y por contrastes, la clasificación de los alumnos según su capacidad en los diferentes ramos de la enseñanza, las Cunas Públicas, las Salas de Asilo, las Beneficencias encomendadas a mujeres, las Escuelas de Artes y Oficios y hasta la preparación de cursos para la adquisición de ideas práćticas de agricultura y horticultura, todo ello está incluído en la magistral obra escrita por Sarmiento.

La educación de la mujer y su bienhechora influencia en el medio social las destaca Sarmiento con vivos caracteres, consecuente con las ideas y las fundaciones, expuestas y realizadas en la República Argentinåapon CBernardino Rivadavia durante su gestión ministerial y su período de mando presidencial. Sarmiento hace justicia al espiritu creador de Rivadavia y a su feliz intuición del papel social de la mujer, al establecer en Buenos Aires, en el año 1823, una Sociedad de damas, bajo la denominación de Socieclad de Beneficencia, para la dirección e inspección de las escuelas de niñas, de las casas de expósitos, de las de partos públicos y ocultos, hospitales de mujeres, colegios de huérfanos y de todo establecimiento público dirigido al bien de los individuos de ese sexo, consigna el artículo $20^{\circ}$ del decreto de ereación, habiendo mostrado las beneficiadas, debemos decirlo, una dulee gratitud para la memoria de su benefactor, al reclamar sus cenizas ausentes de la patria y hoy yacentes en la urna funeraria que, en la plaza pública del Once, parece dar a conocer que el pueblo argentino ha querido sustraer a Rivadavia del amoroso recogimiento de la Recoleta, para colocarlo frente al esplendor opulento de Buenos Aires, donde nacieron y donde su mente forjó perdurables instituciones y bellas obras.

Tampoco omitió Sarmiento preocupación alguna por la educación de los niños, solicitando la fundación de instituciones pro- 
tectoras de la infancia, que ya he entmerado, ocupándose en tierno tono, en contraste con su natural impetuoso, de la vida infantil, dando útiles consejos y fijando reglas pedagógicas, que superviven.

$\mathrm{Y}$ es por eso que nuestros escolares han rodeado en la mañana de hoy, la estatua del gran educador argentino, levantada entre jardines, para que su delicada visión ponga saludable tregua en su ardiente espíritu de combatiente, y cercana a la plaza de Jorge Wáshington, quien condensó en una época, en su alma superior, las vitales ideas políticas y sociales del poderoso pueblo que tanto admiró y amó Sarmiento.

El castizo escritor de "Recuerdos de Provincia" el glorioso panfletario de "Facundo", el eximio autor de "Educación Popular", trabajó, también, empeñosamente, por la paz de América, escribiendo, con concepto imaginativo, "Argirópolis" o "Ciudad del Plata", quimérico proyecto de confederación de la República Argentina, Uruguay y Paraguay, que anteriormente formaran con el Alto Perú, las provineias unidas del Río de la Plata, separadas después, y empeñadas en fratrieida guerra.

Si la América hispánica no reconoció fronteras durante el proceso de la emancipación, confundiendo sus ejércitos en los campos de batalla y sus hombres representativos en las labores del gobierno, prontamente aparece la tendeneia separatista, obrando contra otras fuerzas de cohesión, el error político de España de realizar agrupaciones heterogeneas, diferentes geográficas, las costumbres diversas de las localidades, el orgullo de las ciudades, la emulación de gobernantes y caudillos. La gran Colombia se divide en tres repúblicas y en cuatro las provincias unidas del Río de la Plata, como corolario de esta descomposición, sobrevinieron las guerras entre los mismos pueblos que se unieron en la gesta libertadora.

Sarmiento se duele, con espíritu americano, de estas disputas y de estas separaciones, auspicia y reclama terminar con las enemistades, conciliar intereses, concluír la guerra que ensangrienta las márgenes del Plata y dedicarse en paz a la reconstrucción de la patria vigorosa y unida.

"Militan, dice, en favor de la fusión de los tres Estados del Plata en un solo cuerpo el espíritu de la época y las necesidades de las naciones modernas. La especie humana marcha a reunirse en grandes grupos por razas, por lenguas, por civilizaciones idénticas y análogas". "Los Estados del Plata están llamados por los víneulos con que la naturaleza los ha estrechado entre sí, a formar una 


\section{$-369-$}

sola nación. La dignidad y posición futura de la raza española del Atlántico, exigen que se presente ante las naciones en un cuerpo de nación que un día rivalice en poder y progreso con la raza sajona del Norte, ya que el espacio del país que ocupa en el estuario del Plata, es tan extenso, rico y favorecido como el que ocupan los Estados Unidos del Norte"'.

Propone Sarmiento a la isla de Martín García como capital del nuevo estado, debiendo votarse una constitución liberal e instalarse un gobierno protector de todos los intereses.

Abandonado Sarmiento a sus sueños de una nueva América, ya ensayada sin resultado favorable, deja que su fantasía forje en "Argirópolis" el porvenir de la gran nación futura. "Una plataforma culminante servirá de base al territorio argentino, donde habrá de reunirse el congreso de la unión".

Pierde Sarmiento, por amor al organismo americano, en estas aureolas 'de sueño, el sentido cabal de la realidad de América que apartada, sin duda, del pensamiento de unidad política que él señala en "Argirópolis", conđensa, sin embargo, las etapas de un destino solidario y común.

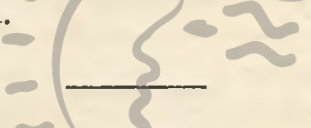

Treinta y ocho años después de haber escrito "Facundo" y a los setenta y tres años ide edad, después de ejercer los más altos cargos públicos, inclusive la presidencia de la Nación Argentina, escribe Sarmiento "Conflicto y armonías entre las razas de América”, su última grandéobra, cenilallquevolviendo sobre problemas tratados en forma local, abarca con visión de conjunto y criterio de sociólogo, el panorama político y social de América hispánica, proponiendo los remedios más urgentes para una necesaria regeneración.

Ha observado Sarmiento que el mal de la ignorancia señalado en "Facundo", no ha desaparecido con el ambiente de régimen político y que en toła la América española, el caso es, más o menos idéntico sin que puedan los pueblos salir fácilmente de un estado inorgánico, en que fuerzas latentes de descomposición actúan contrariando los medios de cultura y de progreso.

Frente a esta desfavorable condición, están los Estados Unidos de Norte América, ofreciendo el espectáculo sugerente de un sólido organismo político, de una composición social segura, de una supremacía económica evidente sobre los demás pueblos de América.

El, mal para Sarmiento, tiene su origen en la política y en la organización social anteriores a la emancipación, y dejándose llevar de su prejuicio por España, pinta, con subido color, sus erro- 
res, exaltando las aptitudes y méritos de Inglaterra, país que admira en su carácter y en sus instituciones.

No hubo, sin embargo, como observa Mitre, que vió las cosas con criterio desapasionado, menos restricciones en la política comercial de Inglaterra con sus colonias que la tenida por España con las suyas, llegando la metrópoli inglesa hasta establecer compañías priviegiadas, como la de la India Oriental "en las cuales entregaba el territorio como propiedad feudal, a título de conquista, reservándose el monarea la absoluta potestad de reglamentar en su comercio". "La libertad de Inglaterra, dice Adam Smith, de cuyo testimonio no puede dudarse, con respecto al comercio de sus colonias, se ha reducido al expendio de su producción al estado bruto, y a lo más, después de recibir su primera modificación, reservando el producto para los fabricantes de la Gran Bretaña. La legislación impedía el establecimiento de manufacturas en las colonias recargaba sus artefactos con altos derechos y hasta les cerraba el acceso a la metrópoli.

Este lado adverso se compone, es cierto, con un monopolio de recursos superiores y de ventajas marítimas evidentes, pero administrado con inteligencia y tolerancia, sin comprometer lis fuen. tes de producción y con un pueblo heredero de una verdadera educación política, lo que no ocurriera con España, que no obstante de no haber tenido propósito deliberado de depresión, sumisión o esclavitud con sus colonias, tampoco supo enseñar nada de administración ni de gobierno propio.

Sarmiento olvida que tsi los conquistadores españoles no resisten comparación con Ios perfegrinos deerNueva Inglaterra, los Quakeros de Pensilvania y hasta con los caballeros monárquistas de Inglaterra que llegaron a Virginia, importaron, sin embargo, aquellos un principio individualista, que fué el gérmen de emancipación de las colonias hispánicas con ideas nacidas en la misma España, revertidas después en contra suya; y que si la mestización, origen del mayor número de males, según Sarmiento, ereó un problema social, evitó indudablemente la crueldad del exterminio, sin perjuicio de que la Argentina, conforme a la tesis sustentada por el eminente historiador Levene, doctor honoris causa de nuestra Facultad de Letras, viene realizando un ensayo sin precedentes, racial y social con la fusión de razas desde los orígenes coloniales y un experimento político de nacionalización , de proyecciones desde 1810.

El cuadro inorgánico queda descrito, señalando Sarmiento, consecuente con la unidad de su pensamiento y de su vida, el remedio, en la educación, añadida a la inmigración.

"Educar al soberano" fué su lema y en este concepto "hizo tanto como predicó: legislador y ejecutor de una nueva cultura". 
"¿Qué le queda a esta América, dice, para seguir los destinos libres y prósperos de la otra?". Nivelarse; y ya lo hace con las otras razas europeas, corrigiendo la sangre indígena con las ideas modernas, acabando con la Edad Media", y arrebatado de admiración exclama: "La América del Sur se queda atrás y perderá su misión providencial de sueursal de la civilización moderna. No detengamos a los Fistardos Unidos en su mareha; que es lo que en definitiva proponen algunos. Alcancemos a los Estados Unidos. Seámos la América, como el mar es el Océano, y en seguida, olvidando un imposible material, por la composición distinta de las razas y el deber de nuestra América latina de conservar la autonomía de su civilización y hasta la autonomía de sus costumbres, concluye: "seámos Estados Unidos".

El gran escritor fué también hombre de palabra, que ocupó todas las tribunas públicas, leyendo generalmente, sus discursos, sin giros retóricos, sin artifieios, sin téenica consumada del orador, pero imponiendo su autoridad, dominando al auditorio con la energía de la palabra, rotunda como su pensamiento, por la pasión del alma, por la convicción profunda, por la dramática batalla, que exhibe su frase, entre la realidad que se opone y la fé que vence.

Académico, coneejal, periodista, gobernador político, diplomático, senador, ministro, presidente de la Nación Argentina, inspector de escuelas, çargo quecdesempeñara/teniéndolo a mucha honra, inmediatamente después de rescindido el mando supremo, en todas estas funciones públicas, encuentra Sarmiento ocasión para exponer su pensamiento sobre la realidad argentina, abriendo nuevas rutas, fiel a su conocida máxima de "hacer, así sea mal, pero siempre hacer", y consecuente con su idea fija de eduear a las masas, difundiendo por todas partes, incansablemente, sin siquiera concebir inconvenientes, su afanoso programa educativo. "Necesitamos hacer de toda la República una escuela! Sí, una escuela donde todos aprendan, donde todos se ilustren y constituír así un núcleo sólido que pueda sostener la verdadera democracia que hace la felicidard de las naciones"'.

La historia argentina de esta época de transición de lo inorgánico a la consolidación ínterna y a la seguridad exterior del país, habrá de fijar para la posteridad, como dos elementos básicos de su progreso, el lema de Sarmiento "Gobernar es educar" y el de Alberdi "Gobernar es poblar", encontrando en la fé de ambos dos grandes y esenciales componentes de la superación nacional; y la pasión política separó al autor de "Cartas quillotanas" del au- 
tor de "Las Ciento y Una", empeñados en durísima polémica y convertidos en implacables enemigos, hoy se encuentran unidos bajo el amparo igualmente amoroso de la inmortalidad.

Como legislador intervino Sarmiento en todos los debates de importancia del Congreso Argentino de su tiempo. La reforma del Código de Comersio, los antecedentes del Banco Nacional, la reforma de las contribuciones, las leyes de ferrocarriles, de inmigración y distribución de tierras, las facultades del Ejecutivo, las atribuciones ministeriales, la libertad de prensa, el voto secreto que fué el primero en patrocinar, el servicio militar, la composición del Poder Judicial, la representación diplomática e innumerables intervenciones en materia de enseñanza primaria, secundaria y superior, representan un sustantivo aporte de Sarmiento a la obra legislativa de su patria.

Llegó Sarmiento al Perú como ministro plenipotenciario el año 1864 mientras se realizaba en Lima el Congreso Americano de la misma fecha, fiel nuestro país a una honrosa tradición de derecho público expuesta, en elevada nota, por Juan Antonio Ribeyro, ministro de relaciones exteriores, también rector de esta Universidad, figura ilustre de la diplomacia, de la actividad universitaria y de la magistratura judicial del Perú, que aspira a establecer-dice así la nota de Ribeyro-el arbitraje como el único medio de transigir todas las faltas de inteligencia y motivos de desacuerdo de algunas repúblicas sudamericanas, añadiendo, que si alguna vez, lo que no es creíble se amagase la independencia de alguna de nuestras repúblicas, seremos unidos en la guerra, como lo somos en la paz, y en tancduraPextremidád, ctrataremos de distinguirnos siempre por la templanza de nuestros actos, por la pureza de los principios, por lo humanitario de los medios bélicos que necesitemos emplear.

Sarmiento en unión del doctor Arosemena, representante de la república de El Salvador, define en el aludido certamen internacional, en su alcance jurídico, el enojoso asunto de Talambo idesde un punto de vista americano.

No fué esta la única relación amistosa de Sarmiento para con el Perú, pues en el orden literario escribió páginas de cariñosa recuerdo aunque a veces de amable ardvertencia para nuestro país, mostrando especial preferencia por Lima a la que llama Sevilla Americana, elogiando la gracia de las tapadas, el buen decir de nuestras gentes, incluso las del pueblo, que "hablan el castellano más correcto de América, como se conservó puro o se formó el italiano en Florencia que era la corte de los Médicis", y dedicando palabras de admiración a la que denomina gran biblioteca de Lima.

Ejerció también Sarmiento la representación diplomática de 
su país en los Estados Unidos de Norte América, su predilecta nación, como ya he dicho, a la que llega por segunda vez en su vida, en época de su mayor plenitud intelectual sorprendiéndole en ese cargo diplomático su elección de presidente constitucional de la Nación Ârgentina, sucediendo al ilustre general Bartolomé Mitre, gran estadista y gran hombre de letras, el creador en la República Argentina, de los modernos estudios históricos. El 12 de octubre del año 1868 asumió Sarmiento el mando supremo de su patria, renovando cn ese día, como su primer acto público, su concepto y su vocación por la educación popular. "Si no la promoviera, dijo Sarmiento, los antecedentes de mi vida quedarían como vana ostentación de aspiraciones, que la posesión del póder y la ocasión de realizarla dejó al descubierto. Quedaría establecido que en nuestro país el influjo del gobierno es impotente para romper con la tradición de ignorancia que nos ha legado la colonización".

Cumplió Sarmiento su palabra y durante su período de gobierno se reformaron todos los ramos de la enseñanza y se llevó a la práctica las más importantes creaciones en materia de educación pública.

Cierto es que hubo ensayos infruetuosos y que la reforma sufrió el recargo propio del temperamento de su autor, empeñado en que nada faltara, pero pese a este y otros defectos, rectificados después, la obra educativa de Sarmiento de 1868 a 1874, continuación de la empezada en 1840 y antecedentes de la que siguiera hasta el mismo día de su mièrte, cobrac profundamente gargentina-él lo dijo al pie de la estatna de Mazzini- Asociándome a vosotros yo no salgo del terreno de mipais "sccisey argentino y vosotros lo sabéis"; la obra educativa de Sarmiento, vuelvo a decir, condensa una evocación y una misión, un đestino que sobrevive, hecho conciencia en la nacionalidad argentina, un mensaje que recoge América de un carácter verdaderamente heroico, o la correspondencia entre los actos y la conciencia, quie es la primera condición exigida por Carlyle, a sus héroes con fuerzas de reacción, de resistencia y de persistencia que desafían toda imitación, que es lo que realmente constituye el verdadero carácter, según Emerson.

$\mathrm{Y}$ en cuanto respecta al desorden que se advierte en la obra de Sarmiento, juzga acertadamente Octavio Amadeo en sus "Vidas argentinas", cuando dice que el desarreglo de sus gestos y de sus palabras era un-desorden meramente exterior, toda vez que en el conjunto de su obra no se percibe ese desequilibrio, al revés de lo que sucede con otros hombres políticos, perfectamente equilibrados en la. apariencia y cuya obra lleva el sello de un desequilibrio esencial.

Concluyó durante el período gubernativo de Sarmiento la guerra con el Paraguay, pero sobrevinieron intensas luchas intestinas, 
siendo su epílogo el asesinato de Urquiza y un atentado contra la, rida del Presidente en las calles de Buenos Aires.

Pese a la gran actividad propia del gobierno, no abandonó Sarmiento un solo día su histórica función de pensador y publicista, escribiendo artículos de combate en la prensa diaria, consecuente con su afición y extraordinaria habilidad periodística.

El patriotismo de Sarmiento lo arrebata de elocuencia el 24 de setiembre de 1873. descubriendo en la Plaza Mayo de Buenos Aires, la estatua ecuestre del insigne y virtuoso general Manuel Belgrano, pronunciando en ese día su inmortal oración a la Bandera:

"Que la bandera que sostiene su brazo flamee por siempre sobre nuestras murallas y fortalezas, a lo alto de los mástiles de nuestras naves, y a la cabeza de nuestras legiones; que el honor sea su aliento, la gloria su aureola, la justicia su empresa" .

$\mathrm{Y}$ en otro lugar de la célebre oración muestra Sarmiento, con palabras de amor, los caracteres sociales, el sentido democrático, el germen profundo de humanidad de la nueva promisora nación, diciendo de la siguiente manera:

"Y a todas las nacionalidades de la tierra cuyos hijos tocan estas playas en busca de un lugar para hacerse un domicilio y una patria, ofrézcoles a nombre del pueblo que esta bandera representa, la protección que ella da gratuitamente, recordándoles sólo que el hombre es familia, tribu, nación, con deberes para con los demás, y que los sentimientos más generosos, el heroismo la gloria, el amor de la patria se amortignan no ejercitándolos y que la elevación del alma humana desciende y desaparece con la satisfacción exclusiva de las necesidades". "Jorge Puccinelli Converso"

La voz siempre firme de Sarmiento se vuelve trémula de emoción un día, en la Recoleta, al pie de la tumba de su maestro de primeras letras. En el silencio del campo santo, invadida, sin duda, su alma por la memoria de su niñez, pliega sus alas victoriosas el presidente de la Nación Argentina, ante los despojos del humilde maestro de escuela corvvertido en símbolo del deber y del honor, pronunciando el glorioso discípulo estas perdurables palabras:

"Si hoy soy honrado con un título que no a todos honra en definitiva, y que por pomposo que sea entre nosotros, no es por sí solo suficiente para llevar un nombre propio cien leguas más allá de nuestra tierra, ni conservar su recuerdo diez años después de haberlo usado, esta manifestación hecha por sus discípulos al maestro Peña y mi participación en ella, mostrarán a la juventud ambiciosa de gloria duradera, que hay caminos escabrosos que conducen a ella haciendo el bien y difundiendo la instrueción".

Debo ya dar a conocer mi último juicio sobre la obra del insigne argentino. 
No puede dudarse, señores y señoras, del genio de Sarmiento que vió realidades que los demás tardaron en percibir, que anticipó acontecimientos que los demás negaron, que anunció como verdades extraídas, algunas de ellas, no de su inteligencia sino del fondo misterioso de su ser, las que sólo lo fueron después por la acción tardía del tiempo; que hizo de la luz una fuerza por la riqueza de su sensibilidad y el vigor sorprendente de su carácter; que aprovechó de todas las posibilidades desde la más alta hasta la más pequeñas, que en intensa lucha contra el medio logró, en momentos culminantes de su creación, derribar el egoísmo y el rencor, haciendo que convergieran todas las energías hacia la unidad que necesitaba su pensamiento; que llegó hasta las raíces vivas y profundas ce la nacionalidad argentina, infundiendo temor o despertando aınor; que abominó de la inercia y de la indiferencia, que no quiso saber si alumbraba el sol o era oscura la noche para llevar a todos los hombres el pan sublime del espíritu; que sólo se entristeció como medio de dar más brío a su pensamiento y más alas a su espíritu, que en la victoria o en la adversidad mostró igual grandeza de ánimo, que vertió su sangre por las ideas, con la pasión que es también atributo del genio, que tuvo fe en que la justicia disipa al cabo todas las tinieblas, que sintió profundamente la fraternidad humana, la fecundidad de la belleza y el beneficio de la legítima libertad que consecuente, en fin, con su idea fija de educar dijo su palabra en todas las formas y bajo todas las frondas para que la América entera la respire como el aire que da la vida.

iSus contemporáneos lo creyeron algunas veces loco pero la posteridad, borradas lasosojabras delesus intemperancias, de su desconsiderada franqueza, de su imprudente sinceridad, restañadas las heridas que la lucha produce, le proclama genio, apagadas las ideas pueriles y sólo brillante la luz que iluminaba su extraordinario espíritu.

Un nobilísimo sentimiento paternal deshizo su vida con la muerte de su hijo "sin saber donde arrojar este pedazo de vida que me queda" y no le faltó nunca afectuosa tolerancia para el verdadero mérito, guardando siempre, sin abdicar de su liberalismo, un recuerdo reverente para sus primeros maestros clérigos y para la memoria del dean Funes, el gran rector de la Universidad de Córdoba. Y no fué tampoco, me parece, subalterno sentimiento la ostentación que siempre hiciera de su valor, sino resentida protesta contra el daño de la burla, el olvido, el abandono y el vacío. Hubo espacio en su alma para el mismo candor. Sin tener con que vivir al dejar la presidencia, solo le pide a su sucesor Avellaneda un secretario que le escriba y una franquicia de correos para poder difundir sus pensamientos, pero cuando se le ultraja, cuando se conflagran los odios en su camino y el estallido de la pasión política 
pretende apagar su estrella, entonces, sacudida su naturaleza por la profunda conmoción de su gran destino, demuele y truena, se empina sobre lo temporal, distingue lo definitivo y en el Congreso Argentino apostrofa su palabra con la claridad de un relámpago. "Yo soy don yo". "Todos los malvados llevan mi marea", y embellecida la fea figura, la tosea planta, "que parece brotada de alguna rajadura de la tierra", arrastrándolo todo, el humilde nacimiento, la soledad, la tristeza, el honor y la gloria de la muerte" dice: "He querido, señor Presidente, que la barra me oiga una vez por todas, para que vea toda la libertad de que soy capaz. $Y$ es una pérdida para el país que ustedes encadenen $\mathrm{y}$ humillen y vejen este espíritu que ha vivido sesenta años, duro contra todas las dificultades de la vida; que ha sufrido la tiranía, que ha sufrido la miseria que ustedes no conocen, y las aflicciones que puede pasar un hombre que no sabía en la escuela sino leer y que desde entonces viene abriérdose camino con su trabajo, su honradez y su coraje". "El día en que me echen mi última retreta podrán uecir en justicia: acompañad a ese cadáver; no volveréis a tributar iguales honores a un argentino más ilustre".

Ya enfermo salió Sarmiento de su patria para buscar salud en Asunción del Paraguay, la amada ciudad, fundadora de ciudades $¥$ ailí plantó su última tienda y allí pronunció, en una escuela su último discurso y expiró, fuera del lecho sentado en una silla, sobre una tierra heroica, contemplando en una aurora la diáfana claridad de un cielo amigo.

Pienso que fué agitada su agonía, quevió la América sin la conciencia todavía de sü destino, cque sùs ojos quisieron deslumbrar aun con una nueva verdad, mientras en su mano repentinamente firme levantaba por vez postrera la antoreha de la civilización que llevó siempre consigo.

Habéis hecho bien, señor Rector, en auspiciar la iniciativa del Instituto Cultural Peruano-Argentino, de conmemorar en esta Universidad, destinada a enaltecer la: obra del pensamiento humano, la fecha cincuentenaria de la muerte de Sarmiento, sintiendo sin duda, el claustro que dolencias del cuerpo que en nada amengua el vigor de una mente extraordinariamente lúcida, no hayan permitido asistir a este acto público, que siendo homenaje a Sarmiento es también homenaje a la idea educativa que encarnó y predicó, al más llamado a estar aquí, al maestro de maestros de esta Universidad, al doctor Alejandro 0 . Deustua catedrático, decano, rector, eminente personificación del saber y del amor a la ciencia, reformador de estudios, la más cabal vocación a la enseñanza que puede con orgullo ostentar el Perú, en este anciano y venerable maestro que a los 89 años de edad y 69 de labor magisterial piensa y produce, y a quien pueden serle 
aplicadas con justicia las palabras que, en cierta ocasión, dijo Sarmiento ide sí: "No soy como algunos viejos que suelen sobrevivir a su propio destino, pues, tengo todavía en la mano el buril y la pluma que fijan las ideas".

Disculpad, excelentísimo señor Embajador de la República Argentina que mis palabras no hayan podido responder a la alta significación de este homenaje al genial educador y hombre de estado, cuya memoria no dejará morir América.

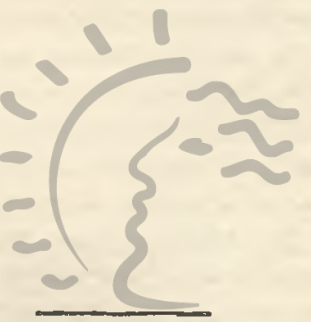

Biblioteca de Letras «Jorge Puccinelli Converso» 